\title{
Institutional reform and government coordination in Brazil's social protection policy
}

\section{Vilmar E. Faria}

Doctor of Sociology
This study, now being published posthumously, examines

Brazil's recent experience in formulating and implementing government social policies and assesses the prospects for establishing a "social authority" for centralizing and coordinating such policies. It describes the complex pattern of exclusion and vulnerability against which social reforms must be instituted in Brazil. It then goes on to review the social development strategy adopted as part of the Plano Real in 1994, which seeks to restructure the financing, outlays and benefits of the social protection system in order to increase its effectiveness, coverage and redistributive impact. Finally, it analyses the coordination of federal social policies, especially at the macropolitical and intergovernmental level, drawing special attention to the creation of sectoral chambers and policy integration mechanisms to replace former bureaucratic coordination structures. 


\section{I}

\section{Introduction}

Over the last fifteen years, the challenges arising in different sectors and resulting from various crises have led to profound structural transformations in Brazil, which have had significant repercussions at the institutional level.

These changes were triggered by a number of factors. Foremost among them were the redemocratization process, which speeded up during the 1980s, and the structural limits encountered by State-promoted industrialization under an umbrella of protectionism. A series of elements contributed to the deterioration of the situation: technological change and the reorganization of capitalism at the international level; the political, economic and social collapse of "real socialism" as implemented under the hegemony of the Soviet Union; the crisis of the Welfare State originally inspired by the social democratic movement and the resultant wave of reforms in this system; the intensification of globalization, above all at the financial level and in terms of real-time access to global flows of information and images; and the growing importance of knowledge as a strategic factor of production.

As a timely -or untimely- reaction to these tremendous challenges, the country had to embark on a wide range of reforms, including the adoption of a new Constitution in 1988 and its partial amendment in 1994; the adoption of various economic adjustment plans, culminating in the successful Plano Real in 1994, which set the seal on a period of far-reaching economic reforms in the areas of monetary stabilization, fiscal adjustment, greater openness of the economy and an ambitious privatization programme; reform of the State, and last but not least, changes in the institutions and programmes for the implementation of social protection policies.

Vilmar E. Faria, Doctor of Sociology (Harvard University), held the post of full professor at the State University at Campinas (Unicamp) and also worked as an assistant professor at the universities of São Paulo and Brasilia, visiting professor at various universities in the United States, and Director of the Brazilian Centre for Analysis and Planning (CEBRAP) and of the Foundation for Administrative Development (FUNDAP) at São Paulo. He occupied the post of Executive Secretary of the Social Policy Department of
Among the main economic reforms were trade and financial liberalization, exchange-rate modification, deregulation, the elimination of foreign investment barriers, privatization and fiscal discipline -all prerequisites for the future expansion of foreign investment. In the social sphere, the main efforts were aimed at concentrating public expenditure in the health, education and infrastructure sectors, although distortions persisted in the social security system. The main lessons to be drawn from the Brazilian reform experience include the net benefit of containing inflation and increasing trade surpluses and the importance of adjusting the financial sector at low cost in terms of GDP and attracting external savings for reinitiating the growth cycle. Since Brazil did not follow the exact sequence prescribed by international financial institutions, the reforms will imply new and important challenges for the country in the near future (Baumann, 1999).

In order to grasp the scope and significance of the social protection policy reforms, it is necessary to take account, on the one hand, of the broader structural context in which those reforms are being applied and, on the other, of the most important features of the Brazilian social situation and the country's social protection system. Mention should also be made of the main dimensions of the social development project adopted under the Plano Real, and the institutional problems associated with coordination of the Federal Government's social policies should be analysed. A brief assessment should also be made of the main results obtained and the considerable amount of work still to be done under the public programme. In the following pages, we will attempt to analyse each of these aspects.

the Office of the President of the Republic from 1996 to 1999, where he contributed to the formulation of the Alvorada project (for poverty reduction in less developed cities), the development of the Community Solidarity Programme, and the incorporation of the Bolsa-Escola bursary project in federal programmes. Subsequently, and until his death on 27 November 2001, he acted as Chief of the Special Team of Advisors to President Fernando Henrique Cardoso.

INSTITUTIONAL REFORM AND GOVERNMENT COORDINATION IN BRAZIL'S SOCIAL PROTECTION POLICY • VILMAR E. FARIA 
II

\section{Social protection problems and policies} in present-day Brazil: a paradox

At the dawn of the 1990s, Brazil's social situation was somewhat paradoxical.

On the one hand, after at least 50 years of rapid economic growth based on import substitution industrialization and an aggressive role by the State as an economic stakeholder, the country had become one of the most dynamic and complex urban/industrial societies on the capitalist periphery, and one of the ten leading economies in the world. It had a large business sector consisting of a wide range of national business entrepreneurs as well as industrialists from the most dynamic economies of the First World (Germany, United States, United Kingdom, France and Sweden, among others). It had already succeeded in developing a modern, large-scale and diversified commercial agricultural system, and although it remained a relatively closed economy, it had managed to establish a pattern of differentiated exports ranging from traditional primary products to consumer durables, automobiles, and even aircraft. It had one of the largest advertising markets in the world and a relatively comprehensive and diversified system of postgraduate education and science and technology studies. Its differentiated occupational and class structure was characterized by high geographic and social mobility and by the existence of an occupationally diversified middle class and quite a significant industrial working class, located especially in the central and southern regions of the country (Faria, 1986).

At the same time, however, the overall picture in the country was still one of serious inequality, exclusion and social backwardness, due to its past as a colonial and slave-based society and the exclusive pattern of protected industrialization. Consequently, it still had a large, poor rural sector, made up of owners of small, extremely unproductive family properties and masses of landless labourers. The cities harboured droves of unskilled manual and non-manual workers, who constituted a large excluded and marginalized sector. Education and health services were backward in terms of both access and quality. Adult illiteracy was close to $20 \%$ and as much as $37 \%$ in the Northeast; average schooling amounted to only 4.9 years and $11 \%$ of children between 7 and 14 years of age did not attend school. Undesirable patterns of social discrimination persisted, based mainly on race, gender and geographic origin. The illiteracy rate was $9 \%$ among whites but $22 \%$ among blacks and persons of mixed race. The white population had 6.2 years of schooling on average, whereas those of African origin had only 4.2 years. Infant mortality, unemployment and lack of access to health services were also disproportionately high among the black and mixed population compared with the white population. When they did have employment, blacks were paid only half as much as whites.

Paradoxically, alongside this complex structure of exclusion, backwardness, inequality, discrimination and vulnerability, by the end of the 1980s Brazil already had quite an extensive State system of social protection, especially compared with the other countries of Latin America and Asia. As one of the pioneers of this system in Latin America -along with Argentina, Uruguay, Chile and Cuba- it already had a broad, complex and costly system of protection. Strongly Bismarckian in inspiration and with a deep influence of the State/ corporatist pattern characteristic of countries where Catholicism exercised a major political and ideological influence, the Brazilian system was, and still is, characterized by uneven and fragmentary benefits linked to the different occupational sectors and elite groups. Because of its markedly State character, it favoured groups with links to the public sector: members of the armed forces, government employees (particularly those of State-owned enterprises), officials of the legislative and judicial corps and of typical State activities such as the diplomatic service, and to a lesser degree industrial workers from the most strategic sectors.

The gradual incorporation of other sectors took place in an uneven manner, and the pattern of organization of the publicly-run social services continued to show limitations in terms of access and quality, and -in the case of education, for example- gave the upper middle classes privileged access to higher education. Taking all three levels of government (federal, state and municipal), the investment and public 
expenditure required by this system represented a little less than $20 \%$ of GDP, the bulk of this expenditure being related to the pay-as-you-go retirement and pension systems and other benefits associated with the corporative system.

The 1988 Constitution, which was the fruit of the struggle against the authoritarian regime, simply confirmed and expanded the foundations of this system, without taking full account of the need for its actuarial restructuring, its fiscal impact or redistributive role, or the challenges that it would have to face in the future, especially those arising from the new population dynamics. Innumerable diagnostic studies made on this system in the 1980 s revealed its incomplete, corporatist, regressive and fragmentary nature. ${ }^{1}$

The crisis of the 1980s and early 1990s simply exacerbated this social situation, disrupted the existing social protection system and heightened the paradoxes in a country marked by deep inequities and injustice. Thus, when the growth based on State-led import substitution industrialization had run its course, as reflected first in the debt crisis and, subsequently, in the worsening hyperinflation, Brazil went through a relatively long period of sharp fluctuations in growth rates reflected in over ten years of economic stagnation. Indexed hyperinflation severely penalized the poorest segments, which were unable to protect themselves, and threw the public sector into disarray. Consequently, the quality of the already precarious public services declined still further, State investment slumped, and some important public-service sectors, such as housing, collapsed entirely.

Thus, at the start of the 1990s the country was sunk in an unprecedented crisis. Between the end of the 1970s and the early 1990s, per capita family income was below 250 reales most of the time, and in the period from 1990 to 1994 it stood at practically the same level as in 1977-1979 (figure 1). The proportion of poor people in the population was over $50 \%$ during the 19821983 crisis, and it remained at around $43 \%$ in the late 1980s and early 1990s (figure 2); in the first half of 1994, immediately after the adoption of the Plano Real, the absolute number of poor people reached a peak of over 67 million persons. The same occurred with the proportion and number of indigents. At the beginning of the 1990s, indigents accounted for more than $20 \%$ of the population $(20.4 \%$ in 1992$)$ and numbered more

\footnotetext{
${ }^{1}$ See in particular the studies by Draibe, Guimarães de Castro and Azeredo (1995) and Faria (1991 a and b).
}

than 30 million, with the proportion rising to $29.8 \%$ in 1993-1994 (figures 3 and 4).

At the beginning of the decade, life expectancy at birth was below 65 years, while infant mortality (43 per thousand for the country as a whole) still varied significantly between urban and rural zones and between regions, ranging from 28 per thousand in urban areas of the south to over 84 per thousand in the rural Northeast. Adult illiteracy and basic schooling rates were incongruous with the degree of wealth and development that the country had attained: $17 \%$ of illiteracy among the adult population and little more than four years of schooling.

Income distribution in Brazil reflects the gravity of the social panorama. Despite fifty years of rapid growth, the Gini coefficient was still around 0.600 at the end of the 1970s and remained at this same level for the following twenty years, with a slight worsening of the situation at the beginning of the 1990s (figure 5).

Paradoxically, however, the country's social spending represented close to $19 \%$ of GDP, including pensions, health, education, labour, housing and basic sanitation, social welfare, programmes to support peasant agriculture, agrarian reform and rural social development. These investments and expenditures, together with the associated direct income transfers, had little distributive impact. Existing estimates -which it should be emphasized are only tentative - show that government transfers at this time did very little to change the appalling income distribution situation in the country.

FIGURE 1

Brazil: Monthly per capita household income (Average for the periods, in 1999 reales)

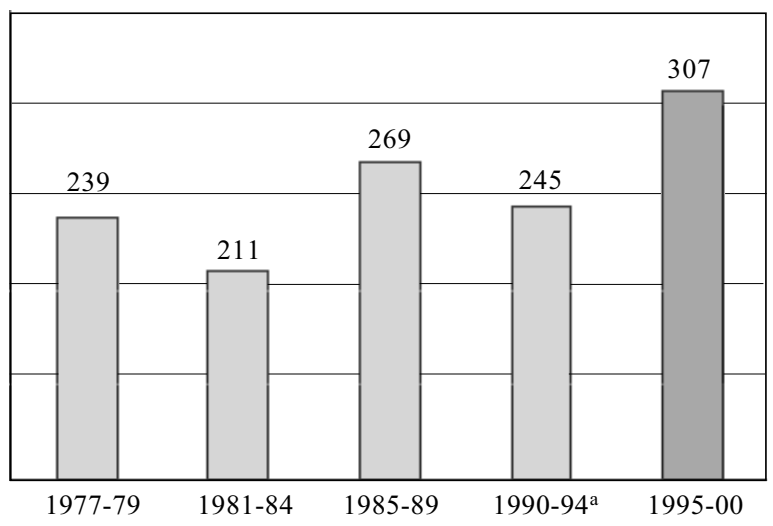

Source: Brazilian Geographical and Statistical Institute (IBGE), national household surveys.

${ }^{a}$ Does not include data for 1991. 
FIGURE 2

Brazil: Percentage of poor persons in each year, ${ }^{a}$ 1977-2000 (Percentage of total population)

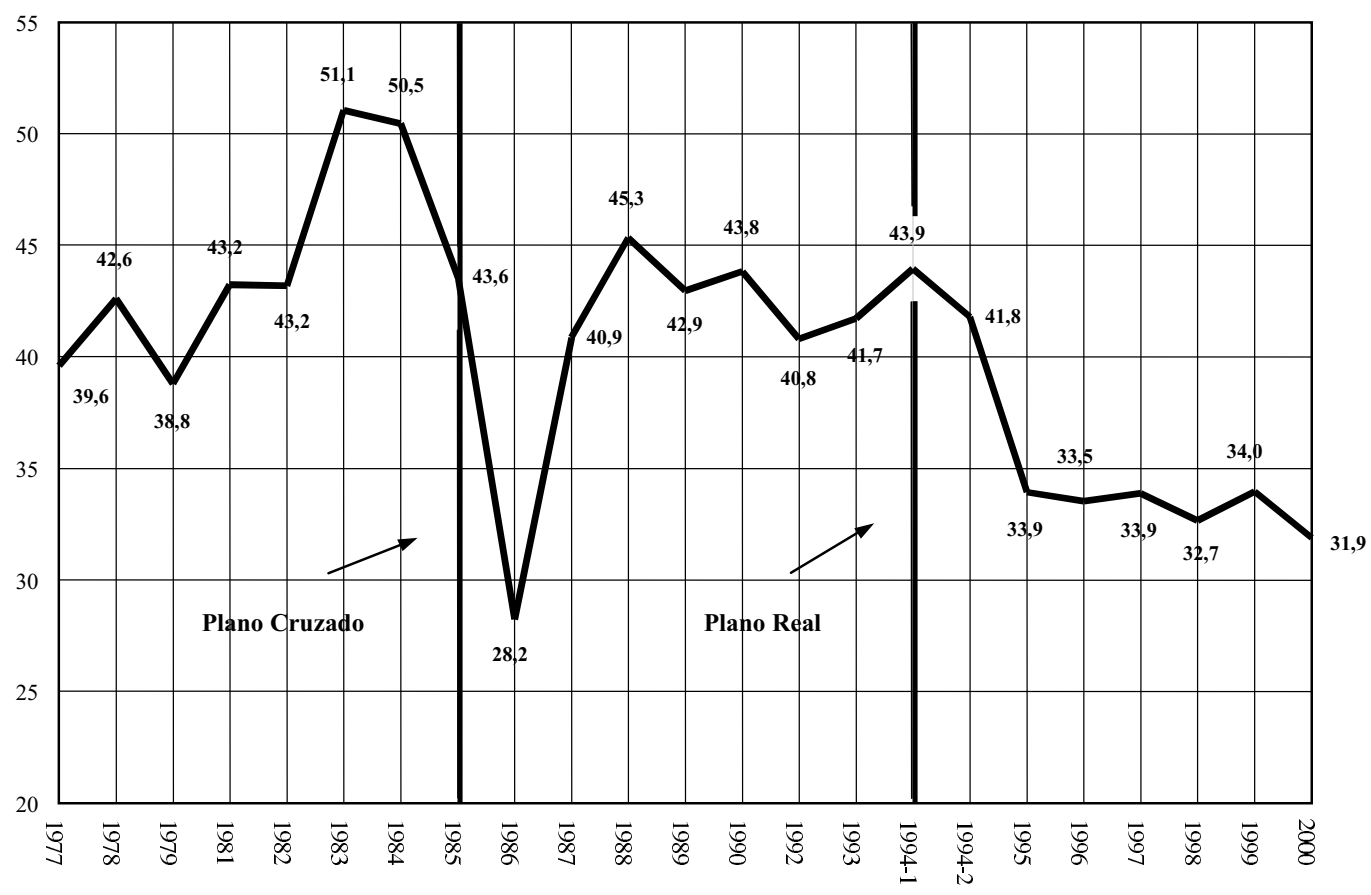

Source: Institute for Applied Economic and Social Research (IPEA) on the basis of IBGE national household surveys.

a The values shown for 1994 to 2000 are estimates.

FIGURE 3

Brazil: Percentage of indigents, 1977-1999 (Averages for periods, as percentages of the population)

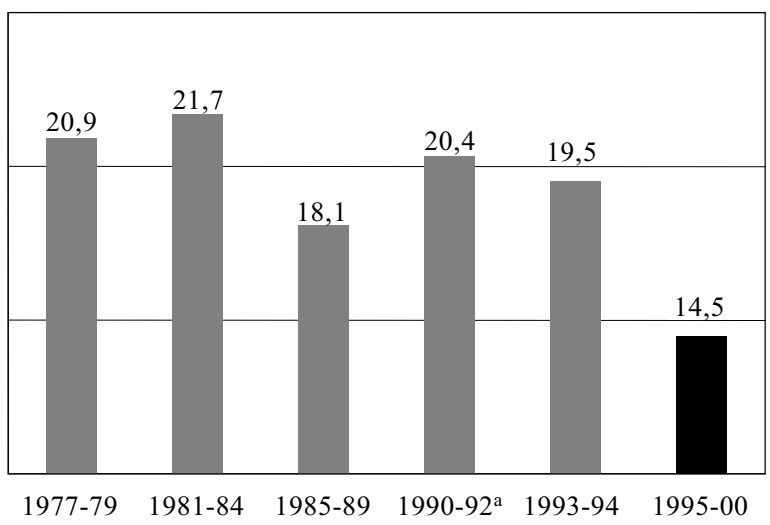

Source: IPEA, on the basis of IBGE national household surveys.

a Not including 1991.
FIGURE 4

Brazil: Total population, poor population and indigent population, between 1977 and 2000 (Averages for periods, in millions)

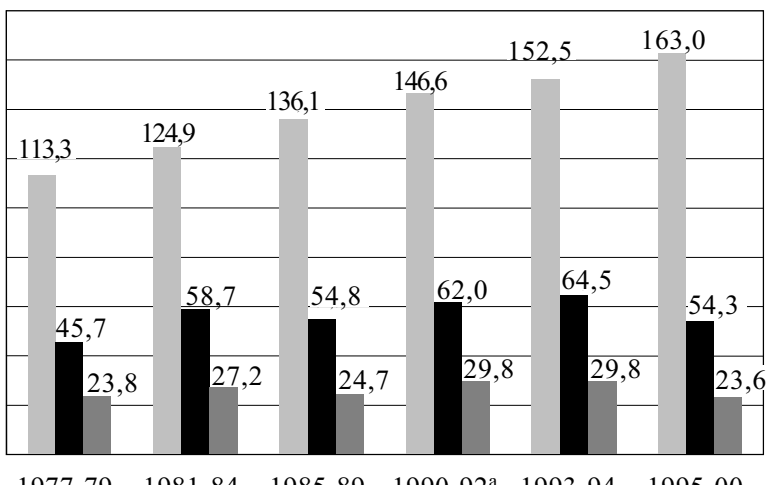

$1977-79 \quad 1981-84 \quad 1985-89 \quad 1990-92^{\text {a }} \quad 1993-94 \quad 1995-00$

Total pop.

Poor pop. Indigent pop.

Source: IPEA, on the basis of IBGE national household surveys and censuses.

${ }^{a}$ Not including 1991. 
The social development of Brazil -including the advances and necessary modifications in the social protection systems, the necessary institutional reforms and, above all, the coordination of government social policies- should be examined against the background of this social legacy, the grave economic and social crisis, the far-reaching transformations in the pattern of growth and State organization, and the urgent need to resolve the acute problems of fiscal adjustment and to confront the recurrent threats posed by the unstable international financial situation.

FIGURE 5

Brazil: Income distribution: Gini coefficient, 1977-1999

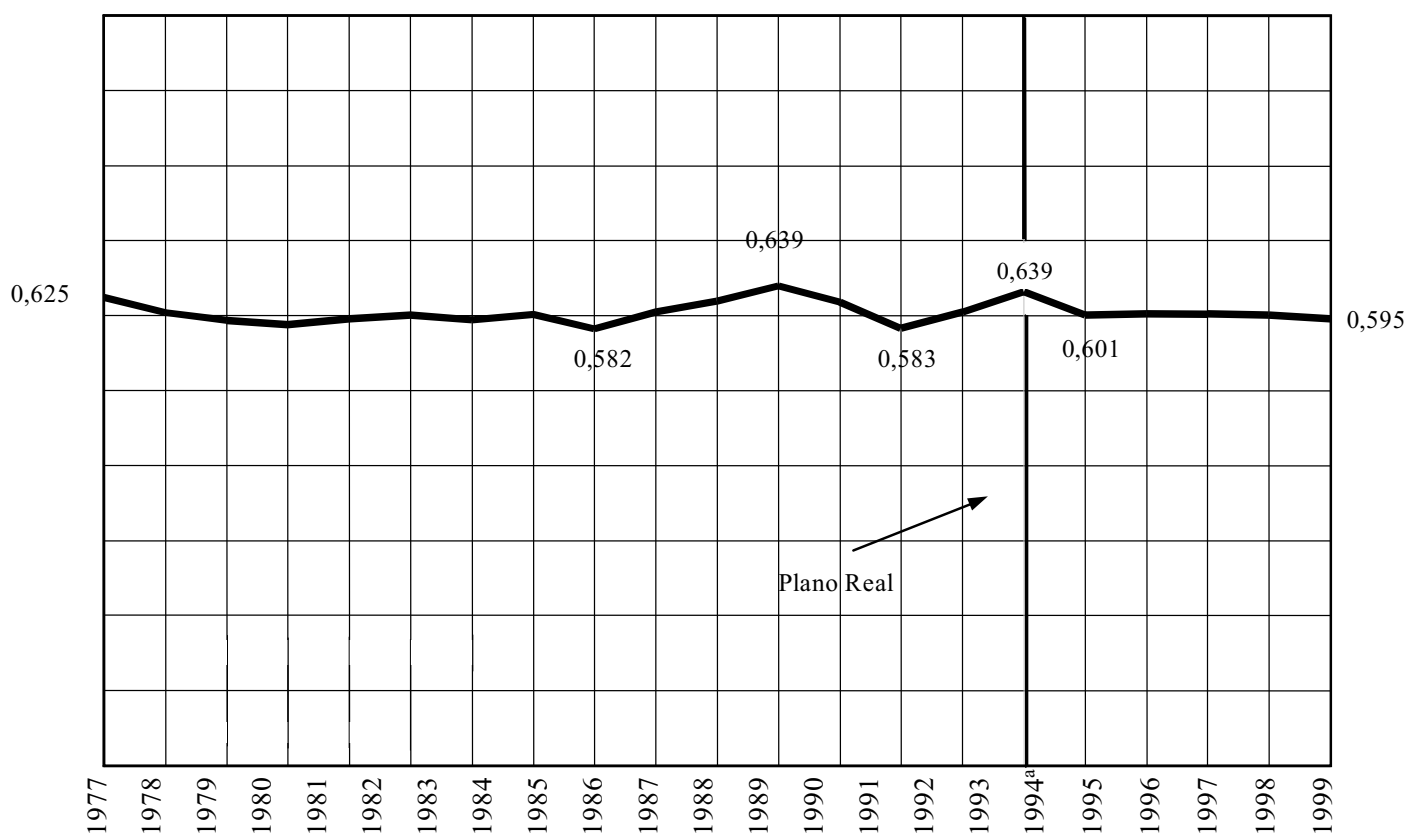

Source: IPEA, on the basis of IBGE national household surveys.

a 1994: estimated value.

\section{III}

\section{The Plano Real and its social development strategy}

After countless unsuccessful attempts at structural adjustment of the Brazilian economy, the Brazilian authorities set about the design, preparation and progressive application of the Plano Real, as a response to the challenges posed by the new forms of the international division of labour deriving from the evolution of world capitalism and the aftermath of the disastrous political experience of the Collor administration (1990-1992), which culminated in the impeachment of the President of the Republic. This plan, which was conceived under the direction of Fernando Henrique Cardoso in the Ministry of Finance during the government of President Itamar Franco (1993-1994), has been applied since then and was further consolidated during President Cardoso's two terms of office (1995-2002). 
Better known for its economic aspects, especially as regards the effort to control hyperinflation and stabilize the currency, the Plano Real has been gradually improved over time. First, it was expanded to encompass not only different aspects of monetary, fiscal and foreign exchange policy, but also measures aimed at greater economic openness and at achieving advances in the privatization process and strengthening the banking system. Subsequently, efforts were made to cover issues relating to reform of the State, investments for bringing the country's physical and social infrastructure in line with the new capital accumulation requirements -in a multiyear investment plan known as Avança Brasil- and the strengthening of regional integration through Mercosur. Last but not least, a comprehensive strategy for social development was included.

This social development strategy, which was conceived and applied in the years of the Cardoso Government, highlights some conditions deemed necessary, albeit not of themselves sufficient, for promoting sustained social development, as may be observed in the successive documents in which it is embodied $^{2}$. It outlines strategic principles to serve as guidelines for the measures to be applied and lists six main points around which the institutional and programme initiatives are to be organized in order to implement the proposed strategy. Finally, in due course, it develops constitutional, institutional, legal and programmatic actions for achieving the desired objectives.

From the programme point of view, the Government adopted some fifty major programmes which eventually enabled it to implement the social development strategy to a greater or lesser extent. This less familiar aspect of the Plano Real is summed up below.

The four fundamental conditions to be simultaneously achieved through the application of the social policies are:

(i) Macroeconomic stability. As recent Brazilian experience has shown, the control of inflation and stability of the currency have an important redistributive effect, quite apart from their contribution to financial and administrative stability.

(ii) Fiscal austerity. Structural adjustment of the public accounts is the indispensable complement to price stabilization, industrial modernization,

\footnotetext{
${ }^{2}$ Cardoso, 1994, 1998 and 2001; Brazil, Office of the President of the Republic, 1996 and 2001.
}

privatization or reduction of the size of the State and restructuring of the financial system to release and support the Brazilian economy's growth potential. Without the consolidation of a new fiscal regime, the scarcity of domestic saving would ultimately inhibit the growth of production and domestic consumption.

(iii) Reform of the State. This functional reform is designed to reorient the role of the State towards the activities where it is really essential, together with administrative reform measures for staff training, reforming the career structure and motivating civil servants in order to increase public-sector efficiency, especially in social services.

(iv) Sustained economic development. Growth rates of at least $5 \%$ are necessary in order to cope with the titanic task of creating enough new jobs over the next fifteen years and achieving the higher GDP growth rates essential for improving income distribution.

The guiding principles of the social development strategy are listed below:

(i) Universality, solidarity and equality of opportunity. Social policies must be based on these principles, without losing sight of the cost-efficiency ratio of each of the programmes.

(ii) Participation. In the design, implementation and evaluation of social policies, it is of fundamental importance to expand the areas of public participation by increasing and diversifying the forms of social participation and public control.

(iii) Decentralization. Decentralization is crucial for public social policy implementation in a country which is as large and heterogeneous as Brazil and which has a strong federal structure. Direct state and municipal participation is essential in sectors such as education and health, although the strategic role of the central authorities in social and regional redistribution must not be overlooked.

(iv) Partnership. Since the Government alone cannot take on the huge number of tasks necessary for carrying out a coherent social policy, it will need to enter into agreements with civil society, as represented by companies, trade unions, universities and nongovernmental organizations. Such agreements could be the basis for developing new public - not necessarily State- ways of tackling problems (for example, in health-related areas).

The Brazilian social strategy is structured along the following lines:

(i) Thorough-going reform of basic social services provided by the public sector, through universal 
coverage in respect of education, health, basic social security and urban infrastructure; improvement of the quality of services; greater efficiency, and the greater redistributive impact of social spending.

(ii) Improving the quantity and quality of opportunities for work and income. This includes greater support for labour-intensive sectors, professional training and retraining, and amendment of the laws governing labour relationships through the expansion of collective labour contracts.

(iii) Application of specific policies for rural areas. Despite the growing urbanization of Brazil, close to $25 \%$ of the economically active population is still employed in agriculture, and many rural migrants to the cities have not managed to integrate adequately into urban production structures. Support for peasant agriculture and the stimulation of new forms of survival through agro-urban companies are therefore essential tasks.

(iv) Increasing opportunities for access to productive assets such as land, credit and know-how.

(v) Development of initiatives and programmes specifically designed to alleviate the most acute forms of poverty in the short term. In Brazil, targeted programmes mean flexibility, because it would not be appropriate to apply the same policies in the periphery of a big city like São Paulo and in the interior of the Northeast region. The Community Solidarity Programme was conceived as a means of coordinating programmes for combating dire poverty and hunger in the poorest regions of the country and trying out new social initiatives in conjunction with civil society.

(vi) Establishment and improvement of direct income transfer programmes. These programmes are a kind of social protection system for situations of need and risk. The main programmes in this respect are: monthly old-age and disability benefits, which guarantee a minimum monthly income for more than one million elderly and poor disabled persons at an annual cost of 3,500 million reales; rural social security, providing benefits to more than six million agricultural workers at a cost of 12 billion reales per year; unemployment insurance and wage supplement benefits, involving annual outlays of 5 billion reales and the Bolsa-Escola school bursary programme, with funding of some 2.5 billion reales transferred from the Federal Government to the municipalities. In total, the cost of federal direct transfer programmes in 2001 was estimated at close to 20 billion reales, or more than $2.5 \%$ of GDP.

This comprehensive and ambitious strategy has become more clear-cut over time, but there are still important deficiencies in its application. It has not been very successful in some of its programme objectives, and above all it is still facing serious fiscal bottlenecks and various constitutional, legal and institutional challenges.

\section{IV}

\section{Institutional aspects of the social development strategy}

Numerous obstacles and bottlenecks persist and must be overcome before the social development strategy outlined above can be properly implemented in Brazil, where it is so urgently needed.

At the fiscal level, there are limitations in at least two respects. On the one hand, a fiscal austerity policy needs to be applied as a necessary but not of itself sufficient condition for achieving sustained social development. This implies severe restrictions on federal, state and municipal public expenditure, further strengthened by the adoption of the tough but indispensable Fiscal Accountability Act. The significant expenditure already incurred and the almost unavoidable natural increase caused by the population dynamics also represent limiting factors, especially in the areas of social insurance and welfare, and health. From the macroeconomic point of view, it would be very difficult to increase the amount of social investment and expenditure, which already stands at about $22 \%$ of GDP, since it is a well-known fact that the higher the level of this effort, the more difficult it is to increase it. The abovementioned restrictions significantly limit the leeway for improving social protection policies.

The main obstacles to be overcome are at the institutional level, however, and are of a legal, political and organizational nature.

INSTITUTIONAL REFORM AND GOVERNMENT COORDINATION IN BRAZIL'S SOCIAL PROTECTION POLICY • VILMAR E. FARIA 
As already indicated, the Brazilian social protection system inherited from the past is part of the problem, not the solution. Its corporatist and fragmentary structure, together with its high cost and operational inefficiency, the host of interests developed around it (politicians, bureaucrats, suppliers and clients) and its regressive structure of benefits has given rise to a set of acquired rights and privileges, especially by segments of the middle class well placed in the judicial, political, bureaucratic and military structures of the country.

Secondly, the poor quality, inadequate performance, restricted access and deterioration of the public social services associated with the worsening crisis of the late 1970s helped to trigger a process of redemocratization under which the new Brazilian Constitution enhanced the legal foundations of the social protection system by spelling out in detail specific requirements for protection which are difficult to fulfill under the new demands of greater competitiveness, the changing population dynamics, and fiscal austerity.

Thirdly, the very consolidation of democracy and the resultant healthy dynamism and combativeness of the different sectors of Brazilian society have transformed the multiple demands arising from the unjust social situation into organized and legitimate pressures, particularly with respect to the fight against hunger, exclusion, discrimination and poverty, calling for well-targeted policies and affirmative action.

Lastly, and to sum up the foregoing, when there is no scope for increasing expenditure or for expansion through upward equalization mechanisms, which would permit the expansion to take place as part of a positivesum game, the only path left for social policy is to restructure financing, expenditure and benefits in order to increase the effectiveness, coverage and redistributive coverage of the system. In other words, the only option is to introduce sweeping institutional changes which imply major conflicts of interest.

Rather than dwelling at length on the details of this vast institutional reform being implemented through dialogue, debate and democratic struggle, we will merely point out its main dimensions and areas of action.

Firstly, it was and still is necessary to change the social policy financing system and the mechanisms for the distribution of resources and allocations among the different spheres of government. Thus, important initiatives were taken with respect to the social security of private-sector workers; the forms of financing and redistribution of federal resources for states and municipalities in the education and health sectors, such as the creation of the Fund for the Maintenance and Development of Primary Education and Teacher Upgrading, and the Minimum Basic Welfare Standards (PAB); the procurement of new sources of funding for health expenditure, such as the establishment of the Provisional Levy on Financial Movements (CPMF), and the establishment of a fund for the special programmes for combating poverty (Poverty Alleviation Programme).

Secondly, it was, and once again still is, necessary to undertake an in-depth reform of the social security institutions, both those that serve private-sector workers and, above all, those serving the different segments of the public sector. Here, because of the extent and scope of the reform and the conflicts of interests that it implies, some progress has been made with respect to social security for private-sector workers, through the modification of criteria relating to age, period of contribution and length of service needed to obtain benefits, but little has been achieved so far with regard to public-sector employees.

Thirdly, for many of these reforms it was necessary to modify the text of the Constitution, which demanded a three-fifths majority vote in both chambers and the approval of the top levels of the judiciary. In a political system with more than thirty parties where all -even the six or seven leading ones- are characterized by personalism and absence of party discipline, and where parliamentary support for the government is organized on flimsy and unsubstantial bases, reforms of this kind always call for a great effort and are a source of constant political wear and tear. Some of these measures affect the interests of the legislative and judicial branches, which makes it difficult to secure their acceptance in these circles of the State. The administration of Fernando Henrique Cardoso, although fairly successful in implementing these reforms -which were also necessary in other spheres implicit in the implementation of the Plano Real-could not avoid this wastage and suffered more than one major defeat, as for example over the contribution of idle public-sector balances.

Lastly, it is important to note that the implementation of a social development strategy like that which took shape in the second half of the 1990s in Brazil calls for redoubled efforts of intra- and intergovernmental liaison and coordination. We will therefore examine this issue, which is the main subject of this article, in greater depth below. 


\section{Harmonization and coordination of social protection} policies. Is a social authority enough?

The importance of policy harmonization and coordination mechanisms cannot be overstressed. This importance increases still further with some factors, however, especially: the size and heterogeneity of the country; the complexity and institutional differentiation of the State or public policy-making apparatus; the volume and complexity of the financial resources involved; the form of State organization (unitary, federated or confederated States); the systems or regimes of government (democracies or dictatorships, constitutional monarchies, coalition-based presidential systems, parliamentary regimes, two-party presidential systems, etc.), and the prevailing modalities of supply of public services (centralized State, decentralized State, decentralized public, philanthropic liberal, marketbased liberal, etc.). These factors, in turn, affect the definition of the main problems of policy harmonization and coordination and, consequently, the possible solutions.

Our own experience in the management and evaluation of social policies in Brazil enables us to shed some light on their recent development.

Brazil is a country of continental dimensions with a strong and unique federal system: the federative entities, apart from the Union, consist of 27 states, a federal district and almost 6,000 municipalities. It has an incipient but vigorous democracy with an active National Congress (Senate and Federal Chamber) in which more than twenty parties are represented, a complex and differentiated judicial system, a free and aggressive press, and a system of government based on free and competitive elections, where the representatives of the Union, the states and the larger municipalities are chosen in periodic elections held in two rounds. At the federal level, the system of government may be defined as a "coalition-based presidential regime", which involves the formation of complex and unstable political alliances both in order to be elected and, even more so, for governing.

The responsibilities for executing the different elements of Brazilian social policy -which involves annual resources in excess of 300 billion reales- are divided up among the Union, the states and the municipalities. At the federal level, the social budget, which represents about $80 \%$ of the total budget of the Union ( 170 billion reales out of a total of 210 billion in the year 2000), is distributed among some ten ministries. Five of them -Social Security and Welfare, Health, Education, Peasant Agriculture and Agrarian Reform, and Labour and Employment- are large bureaucratic structures with tradition and influence, which handle enormous resources and are responsible for the financing and regulatory control of policies and programmes which, together, serve more than 150 million people.

Implementing the more than fifty programmes through which the social protection measures are expressed involves complex intergovernmental relationships at the federal level and no less complex intergovernmental relationships with other entities of the federation. In addition, many of these programmes also have normative or regulatory councils, made up, in varying proportions depending on the council, of representatives of the Federal Government, the states, the municipalities, specific social segments -such as employers and workers- and of civil society as a whole. These councils are often split up into federal, state and municipal councils.

These characteristics, which are of course not peculiar to Brazil, pose considerable harmonization problems for budget design and preparation, and for the regulation, implementation and evaluation of social policies. These are exacerbated by the demands of the reforms now being made in the social protection system under the Plano Real.

Four aspects of this problem, as reflected in Brazil's recent experience, are highlighted below together with a brief account of the initiatives taken and an initial evaluation of their successes and failures.

The first, most general and most decisive aspect is that of the problems of macropolitical harmonization and coordination, especially as regards financing and budgeting, on the one hand, and political coordination for carrying through the desired reforms, on the other.

In Brazil, the entities responsible for these functions either come under the Office of the President

INSTITUTIONAL REFORM AND GOVERNMENT COORDINATION IN BRAZIL'S SOCIAL PROTECTION POLICY • VILMAR E. FARIA 
of the Republic and receive an explicit mandate, together with the support and direct participation of the President, or else they are divided up among the Civil Department, the General Secretariat of the Office of the President of the Republic, the Office of the Attorney General of the Union and the Office of the Special Advisor in the President's cabinet. The Minister in charge of the General Secretariat of the Office of the President is responsible for liaison and coordination between the Executive and Congress, state Governors and political parties. In addition to their specific functions, the Office of the Attorney General of the Union and the Office of the Special Advisor assist the President and ministers in fulfilling these tasks of coordination and liaison.

In this respect, the most important initiative undertaken to improve the federal administration's performance was the creation of sectoral chambers, which bring together ministers by subject areas or macro-problems, under the operational direction of the Minister in charge of the Civil Department. The following sectoral chambers were created from the start: the Economic Policies Chamber, the Infrastructure Chamber, the Social Policy Chamber, the State Reform Chamber and the Security and Justice Chamber. They meet regularly -weekly or fortnightly- and are made up of the Minister in charge of the Civil Department -who coordinates them- the Secretary General, the Minister of Finance, the Minister of the Budget, Planning and Management, the sectoral ministers and the presidents of decentralized agencies and state banks, where appropriate. Some of these chambers also have an executive secretary, who is responsible for putting into effect any decisions that may be adopted. The President of the Republic participates actively in these meetings as often as deemed necessary by the Minister in charge of the Civil Department and the Executive Secretary of the Chamber. At first, the composition of these chambers was fixed, but experience has shown that it is more appropriate that it should vary depending on the problems of harmonization and coordination to be addressed.

These chambers have had varying degrees of success; among the most successful are the Economic Policy Chamber (which meets once a week and is almost invariably attended by the President of the Republic), the Infrastructure Chamber and the Social Policy Chamber.

The Social Policy Chamber has acted as the coordination mechanism for the social development strategy being applied in Brazil. Its relative success (especially in the first years of its existence and of the application of the strategy) is attributable to four factors, all of a political nature: the active commitment of the central government authorities, especially the Office of the President of the Republic; the general coincidence of views, although not without conflicts and arduous negotiations, among the ministers of the main social areas (social security, health, education, labour, and peasant agriculture and agrarian reform); the fact that the majority of its members are highly skilled technical staff and persons enjoying the highest trust by the President of the Republic; and the sensitivity and discipline shown by the economic authorities -although once again not without conflicts and disagreements- with respect to the decisions taken in the Chamber and endorsed by the President of the Republic, although the point of view of the social areas has not always prevailed.

From this point of view, recent Brazilian experience does not confirm that it is necessary or even desirable to set up a "social authority" in the sense of a bureaucratic superstructure under the control of a ministry which has operational powers in some or all of the sectoral areas of social policy. An initiative of this type would not be politically viable and would be operationally ineffective. In contrast with the situation in the economic area, where the operational mechanisms are relatively few and highly efficient -the budget, the interest rate, the exchange rate and the control of income, among others- in the social area there are many more instruments albeit of more limited effectiveness. Moreover, a considerable number of the operational technical staff work in sectoral ministries, and no matter how deficient they are now, centralizing them in a single superstructure would only add to their inefficiency. The Brazilian experience points rather to the need to reform and strengthen the sectoral structures from the functional and technical viewpoint, increasing their strength, prestige and political power and developing effective mechanisms rather than bureaucratic coordination structures.

A second important aspect of the problem of coordination refers to social protection activities which involve conflicts and which require collaboration between different sectors of the social area of the Federal Government for the implementation of a programme or project. A significant number of such programmes and projects, above all the most innovative ones, which seek to reform the profile of Brazilian social policy, call for such collaboration. Thus, for example, the Bolsa-Escola scholarship programme requires close 
operational collaboration between the Ministries of Education, Social Security and Welfare, and Justice, as well as the Federal Economic Fund.

The mechanism developed by the Federal Government for dealing with problems of coordination arose originally within the Social Policy Chamber. It was created by an executive committee of the Chamber and coordinated by its secretary, and it was given a flexible format in order to help resolve the problems of the executive secretaries of the respective ministries, whose basic function is to put the policies, programmes and projects into practice. Problems of integration, liaison and operational coordination for which no solution is found at this stage are brought before the ministerial level of the Chamber.

Although the success of this initiative was greater than that of macropolitical coordination, it likewise varied from one programme to another, due more to political and administrative factors than to problems of bureaucratic centralization. These factors include the technical and managerial capacity of the sectoral executive secretaries, relatively long administrative continuity, convergence of views on the main lines of the social development strategy, the degree of political support received by executive secretaries from their respective ministries, and the legitimacy that they manage to achieve together with their respective administrative apparatus.

A third aspect of the coordination of social policies at the federal level refers to problems relating to the regional and social orientation of programmes and their convergence. Critical diagnostic studies of Brazilian social policy have always underscored two major problems: the lack of targeting of some programmes for combating poverty and regional inequality, on the one hand, and the lack of synergy and convergence of the programmes on the other. The most underprivileged sectors of the Brazilian population did not have access to social safety nets, lacked targeted programmes, and many programmes converged only in a few areas and sectors, excluding many others, especially the poorest and most underprivileged. Reform of the Brazilian social protection system called for an effort to target some programmes and ensure their synergy and convergence in areas given priority because of the deficiencies involved. It should be mentioned that many of these programmes are of a sectoral nature and the technical and operational capacity for implementing them therefore lies in the sectoral administrative structures. Furthermore, intergovernmental linkages and coordination are crucial for carrying them through, in addition to inter-ministerial coordination

On the basis of their own experience -especially regarding the unsuccessful initiatives of this type taken within the framework of the Community Action Secretariat in the early days of democratization- and other experience with the many social funds established in the 1980s, the Brazilian decision-makers had dismissed the idea of concentrating these targeted programmes and convergence mechanisms within a single agency, since the clientage frequent in this type of agency, the widespread discredit of sectoral bodies, the neglect of the technical, political and administrative capacity accumulated at the sectoral level, and the bureaucratic conflicts implicit in a solution of this kind made it advisable to seek new alternatives.

Over time, the Brazilian Federal Government developed a set of procedures, mechanisms and structures for dealing with this difficult issue. The starting point was the creation of a programme under the Civil Department of the Office of the President of the Republic, known as the Solidarity Action Programme, which, after passing through various stages, has split up into three or four mechanisms and structures.

On the one hand, the Federal Government set up and provided logistical and administrative support for a Council made up at present of four ministers (of the Civil Department, Finance, Planning and Justice), twenty persons from different segments of civil society with a recognized record of participation in initiatives for combating exclusion and poverty, and Ruth Cardoso, an anthropologist and university professor with a long career as a militant in social movements and also First Lady of the nation. Through this Council, partnerships are being formed between the government (federal, state and municipal) programmes, sectoral programmes and different sectors of civil society (firms, universities, trade unions, churches, etc,), in order to develop innovative social policy activities in conjunction with segments and regions selected for their needs and deficiencies. Some of the most successful initiatives in this area are: the literacy programmes for young people, financed by private firms with support from the Ministry of Education; the professional training programmes for young people, developed by non-governmental organizations, prefectures and trade unions, with the support of private firms and the Ministry of Labour; the incentive programmes for voluntary action, with support from the Ministry of Justice, and a programme for mobilizing the university community for the

INSTITUTIONAL REFORM AND GOVERNMENT COORDINATION IN BRAZIL'S SOCIAL PROTECTION POLICY • VILMAR E. FARIA 
execution of community development projects with support from the Ministry of Health and Education, the armed forces and private companies. These initiatives, which in general began on an experimental basis and on a small scale, spread once they were successful and took in different segments of both the public and the private sectors as well as the tertiary sector.

After a few failed experiments, the Federal Government is now pushing forward two initiatives, both coordinated by the Office of the President of the Republic, under the operational responsibility of an executive appointed by the President; the objective of these initiatives is to carry out in a coordinated and synergetic way a subset of programmes for the poorest areas in the country, selected according to social indicators such as those included in the UNDP Human Development Index and available to all municipalities in the country.

The first of these, referred to as the Alvorada Project, consists of a set of twelve programmes prepared within the framework of the ministries of education, health, social security and welfare, and sports and tourism, among others. It is being supported by a Poverty Alleviation Fund, set up by the National Congress, whose purpose is to provide Brazilian municipalities where the human development index is very low (under 0.500) with the basic infrastructure necessary for social and human development activities. The programmes are still being conducted on a sectoral basis. The objective of the initiative is to ensure that these sectoral programmes reach those municipalities on a priority basis and that they are executed jointly by the authorities and local civil society. Their problems of intersectoral coordination are dealt with and resolved within the ambit of the Office of the Executive Secretary of the Social Policy Chamber.

The second initiative, which is part of a programme called the "Active Community", is of more limited coverage and scope and is oriented towards supporting community activities for integrated local development. In each state, the poorest municipalities whose inhabitants have shown some capacity for mobilization, organization and action are selected with a view to helping them to find new ways of boosting and developing their respective regions. On the basis of the organization and micro-entrepreneurial training ("thrust") of these communities, needs and demands are identified and the Federal Government seeks to mobilize its programmes in support of such local development efforts.

As is evident, rather than establishing centralized bureaucratic structures, these initiatives are aimed at creating inter- and intra-governmental coordination with political support from the central government authorities.

A fourth aspect of social policy coordination refers to the continuity and administrative effectiveness of social programmes. From the budgetary standpoint, the aim is to set up mechanisms to protect the main social programmes from the cyclical variations and expenditure cuts imposed from time to time by the exigencies of fiscal balance. Two initiatives have been taken in this area, both within the framework of the Ministry of Planning, the Budget and Management.

The first of these initiatives, the "Avança Brasil" programme, embraces a selected subset of programmes -fifty programmes in the different areas considered to have priority by the Government and comprising infrastructure, social development and the generation of knowledge- - which have budgetary priority and for which special management, follow-up and evaluation mechanisms have been developed. This initiative also includes another group of twelve programmes whose budgetary items were maintained even in various circumstances which made necessary cuts in expenditure.

The second initiative, referred to as the Social Safety Net, was developed in the context of the negotiations conducted by Brazil in 1998 with the International Monetary Fund (IMF), the World Bank and the Inter-American Development Bank (IDB) with a view to obtaining the support of these organizations in order to protect the Brazilian economy from the speculative attacks and financial crises that periodically threaten emerging economies. In addition to targets for controlling inflation and reducing the public deficit, commitments and physical and financial targets were assumed by the government in respect of twenty-two programmes considered essential for protecting various of the poorest segments of the population in such crisis situations (for example, maintaining the necessary resources for the payment of unemployment insurance and monthly old-age and disability pensions for poor disabled persons, together with the resources for financing primary education).

Here, once again, the idea was to create operational mechanisms with political backing, rather than centralized bureaucratic structures.

Finally, mention should be made of another aspect of the harmonization and coordination of social policies: the relationships between the different levels of government. In Brazil, although the Federal Government has always played a strategic role -and 
should continue to do so- in the financing and establishment of guidelines for social protection programmes, their operational execution is becoming increasingly decentralized and is left to the states and municipalities. This need for decentralization -since citizens do not live in the Union as such but in one of the municipalities- poses enormous problems of coordination and articulation in a country as large as Brazil and with its very special federal system. Although numerous initiatives are underway for addressing these problems, they are so highly dispersed and persistent that it is unlikely that the Brazilian experience can serve as an example for a large-scale project that could be successful in this respect, except for the examples given earlier.

Our personal and pragmatic conclusion, based on the problems of a country like Brazil, is that setting up a centralized "social authority" is neither necessary nor even advisable, if by such an authority we mean a new bureaucratic structure that concentrates and centralizes social policy initiatives. What is needed -apart from the political thrust of the central authorities- is the creation of coordination and liaison mechanisms that have legitimacy, political support and technical capacity.
Our experience also suggests that the recovery and functional, technical and administrative enhancement of the sectoral organs is a fundamental requirement for improving the performance of governments in the social sphere. In this respect, some of the activities relating to reform of the State and improvement of State management should be aimed at the upgrading of public employees involved in end activities (teachers, doctors, social assistants, etc.) as well as more thorough professional training for staff engaged in instrumental activities in these sectors (managers, business agents, human resources staff, computer staff, etc.), by stimulating and rewarding healthy competition, good working performance and career advancement. In our view, as long as the difficulties arising from the existence of old, outworn bureaucracies, which lead to the devaluation of the public service, continue to have their adverse effects, strategies based on the idea of creating new structures while allowing the old ones to gradually waste away will be doomed to failure.

Lastly, we wish to emphasize how important it is, for the success of coordination and liaison mechanisms, to form a politically cohesive social team which can identify with the social development strategy proposed by the head of the executive power and which is technically competent.

\section{VI}

\section{Conclusion: an overview of the results obtained}

It would be beyond the scope of this study to make a detailed evaluation of the results of Brazilian social policy over the last ten years. Attention may be drawn to three aspects in this respect by way of conclusion, however.

Firstly, there are still major challenges to be confronted in terms of improving the various social indicators, in terms of the coverage, effectiveness and quality of publicly provided social services, especially health, education and public security, and in terms of policy coordination and liaison mechanisms or even the reform of the Brazilian social protection system, especially as regards its redistributive role.

Secondly, while it must be recognized that much remains to be done, the objective results of the Plano Real in the social area are unquestionable. In spite of budgetary constraints, federal social expenditure reached a record level between 1993 and 1999, both in absolute amounts and in terms of per capita expenditure (figures 6 and 7).

Profound and far-reaching transformations were achieved in education, especially at the primary level: by 1999 , adult illiteracy had fallen to $13.3 \%$ (figure 8 ); the rate of school enrollment of children between 7 and 14 years had risen to $95.7 \%$ (figure 9); secondary school enrollment had grown by close to $68 \%$ in six years; the rates of school desertion and grade repetition were lower, and there are quite a substantial number of projects for taking children out of the labour market and putting them all in school. The Bolsa-Escola school bursary programme will serve 10 million children in the next year, including practically all the children of the six million poorest families (Brazil, Office of the President of the Republic, 2001).

In the field of health, the Brazilian programme to combat AIDS has become a model for the entire world.

INSTITUTIONAL REFORM AND GOVERNMENT COORDINATION IN BRAZIL'S SOCIAL PROTECTION POLICY • VILMAR E. FARIA 
FIGURE 6

Brazil: Federal social expenditure, 1980-1999 (In billions of 1999 reales)

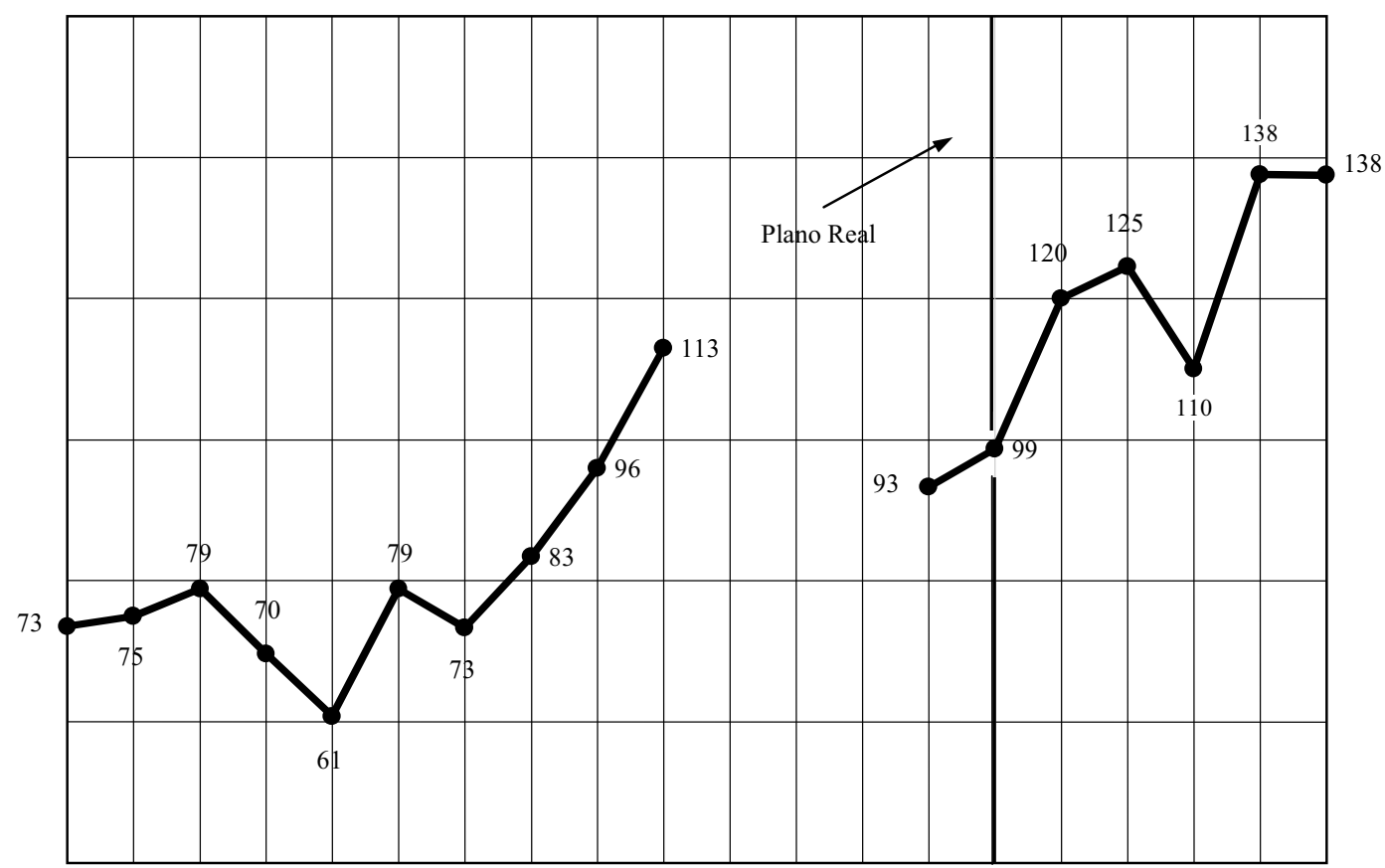

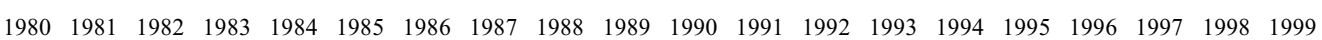

Source: IPEA/DISOC, on the basis of monthly statistics from the SIAFI/SIDOR systems.

FIGURE 7

Brazil: Per capita federal social spending (Annual averages, by period, in 1999 reales)

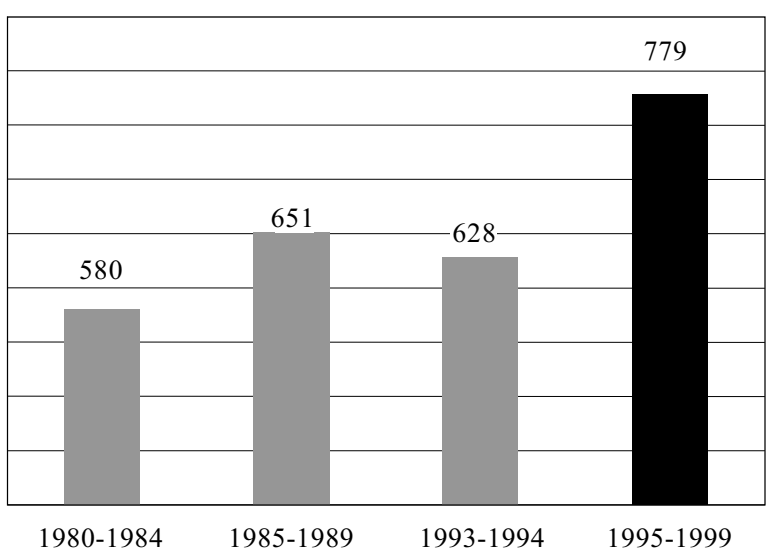

Source: IPEA/DISOC, on the basis of monthly statistics from the SIAFI/ SIDOR systems.
FIGURE 8

Brazil: Illiteracy rates among the population aged 15 years and over, 1983-1999

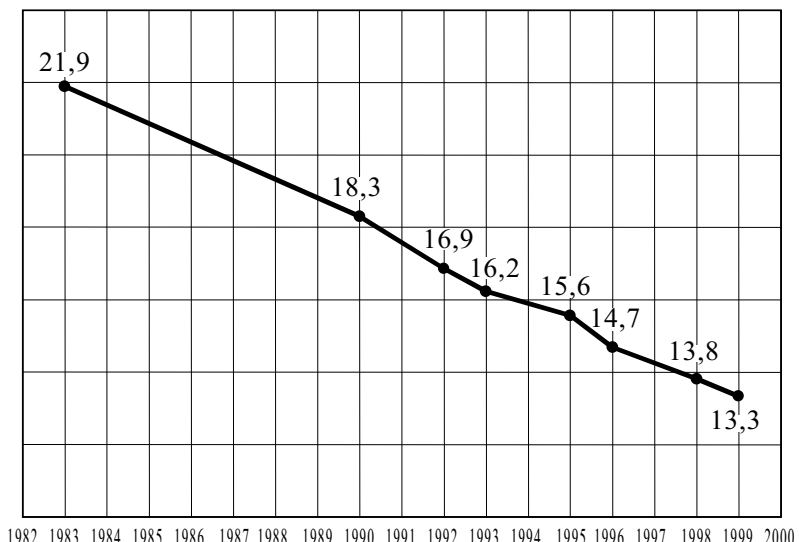

Source: IPEA, on the basis of IBGE household surveys. 
FIGURE 9

Brazil: Enrollment rate in the population 7-14 years of age, 1990-1999

(Percentage attending school)

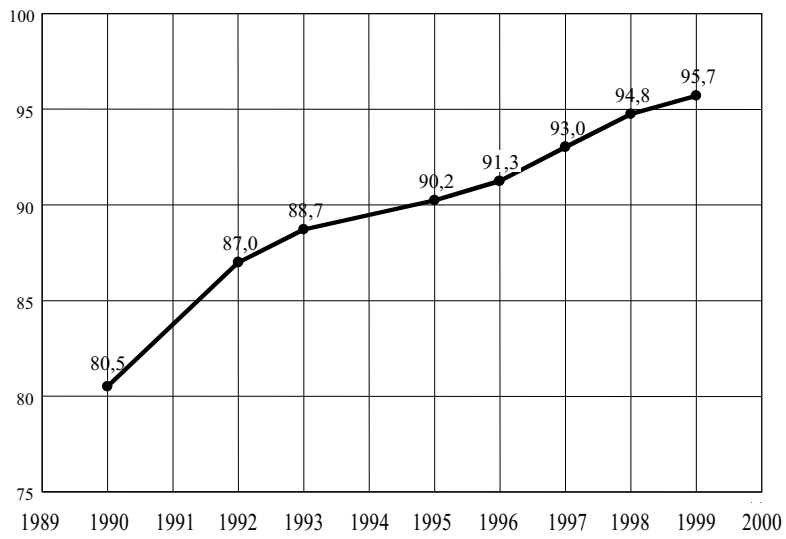

Source: IPEA, on the basis of IBGE household surveys.

Important innovations are being introduced, such as support for generic drugs and the establishment of a basic supply of medicines. The Family Doctors Programme now serves 3,230 municipalities with an estimated population of 38 million. The Community Health Agents Programme, which supplements the former, has 144,199 agents in 4,562 municipalities and serves 82 million persons. The national immunization campaigns are permanently in operation, and in the year 2000 child mortality fell to 35.3 per 1000 live births (figure 10). Federal financing for health increased from 14,800 million reales in 1995 to 26,000 million in 2001 .

With regard to agrarian reform, 465,000 families received land in 1995, which is double the number of families benefited in the 30 years between 1964 and 1994. Almost 18 million hectares were expropriated for agrarian reform, and in six years loans in excess of 7 billion reales were granted to peasant farmers (figure 11).

The efforts to eradicate child labour which were begun in 1996 have given good results, guaranteeing attendance at school for almost 400,000 children and adolescents who previously worked in menial or degrading jobs (figure 12).

In the labour field, the programme to upgrade the professional qualifications of workers (PLANFOR) helped to increase the beneficiaries' employment and income possibilities, to raise productivity and competitiveness, and to give greater employment stability. Training was provided to 11.3 million workers between 1995 and 2000; more than 3 million received
FIGURE 10

Brazil: Infant mortality, 1990-2000

(Per thousand live births)

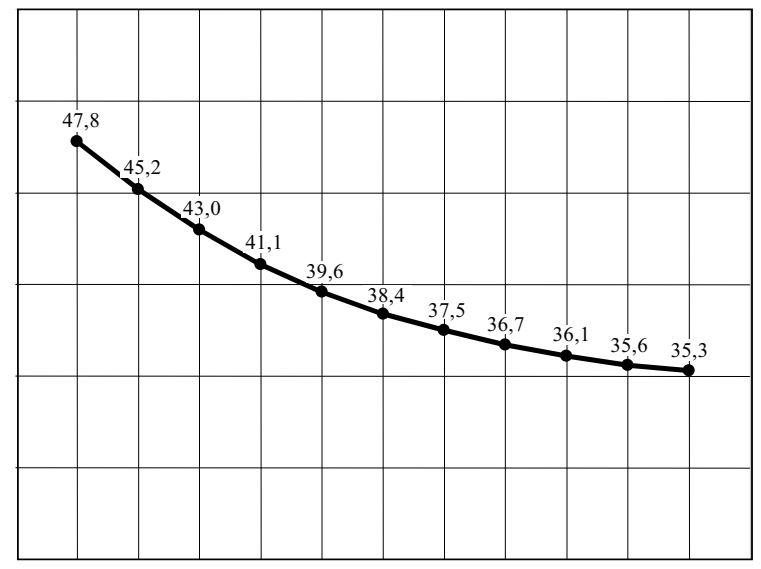

$\begin{array}{lllllllllllll}1989 & 1990 & 1991 & 1992 & 1993 & 1994 & 1995 & 1996 & 1997 & 1998 & 1999 & 2000 & 2001\end{array}$

Source: IBGE and Ministry of Health.

FIGURE 11

Brazil: Annual settlement of landless families, 1995-2000

(Total number of families settled)

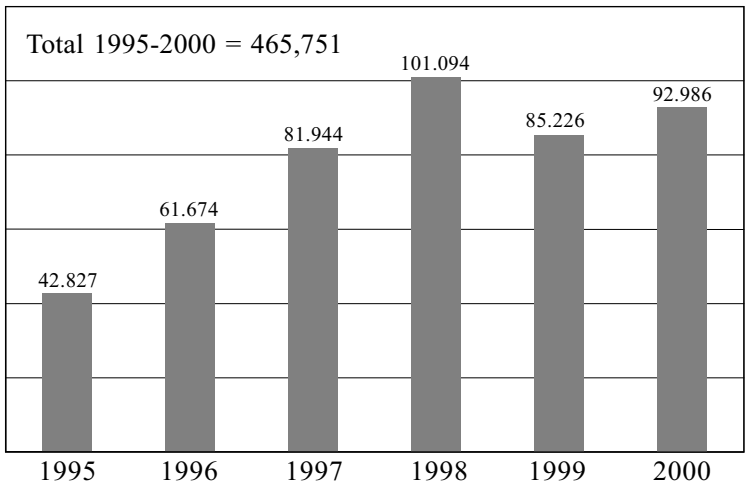

Source: Ministry of Agrarian Development.

training in 2000 and another 4 million are estimated to have been trained or retrained in 2001. The Employment and Income Generation Programme (urban and rural PROGER) is another important initiative which provides financing for training activities as well as technological assistance to workers. More than 1 billion reales have been allocated annually to this programme (Cardoso, 2001).

Substantial progress has been made in direct income transfers to individuals and families; federal programmes of this kind (such as the rural pensions programme, unemployment insurance, and benefits 
FIGURE 12

Brazil: Incidence of child labour (10-14 age group), 1992-1999

(Percentage of children economically active in this age group)

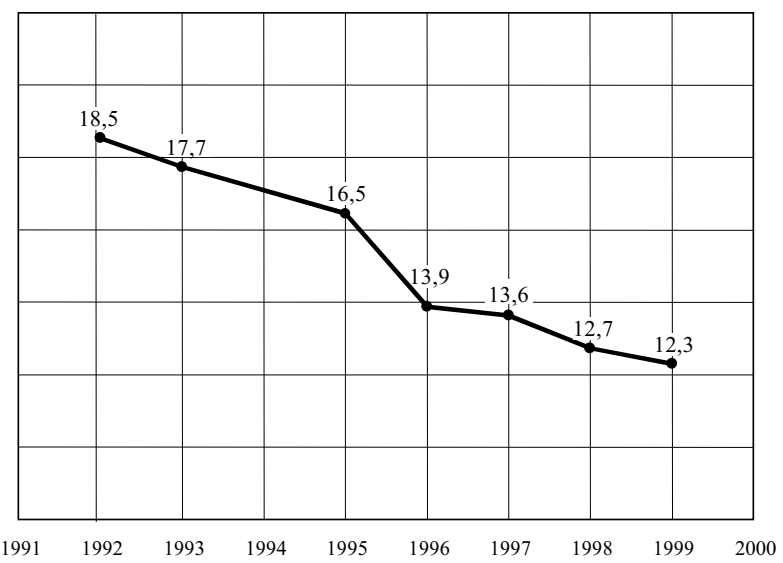

Source: IPEA, on the basis of IBGE national household surveys.

under the Welfare Organization Act (LOAS), the BolsaEscola school bursary programme and the BolsaAlimentação food allowance programme) account for outlays of more than 20 billion reales per year.

In the seven years during which the Plano Real has been in operation, with all its various repercussions, the percentage of poor persons has gone down from $43.9 \%$ to $31.9 \%$ and the percentage of indigents from $19.5 \%$ to $14.5 \%$. All social indicators, except unemployment and underemployment, show significant improvements.

An indicator which reflects the increase in purchasing power resulting from the fall in inflation is the access to consumer durables. Between 1992 and 1999 , the percentage of households with television increased from $73.4 \%$ to $87.8 \%$; those with a refrigerator, from $70.2 \%$ to $82.8 \%$, and those with a telephone from $17.5 \%$ to $37.6 \%$ (figure 13 ).

Although income inequality, which has been intractable for more than thirty years, is still very high, it has nevertheless shown a slight decrease.

Thirdly, it should be noted that Brazilian public opinion, and especially the opposition, nevertheless find little cause for complacency in these results, however objective and significant they may be. The social question continues to be a source of discontent and dissatisfaction for large segments of the population.
FIGURE 13

Access to durable goods, 1992-1999

(Percentage of households owning such goods)

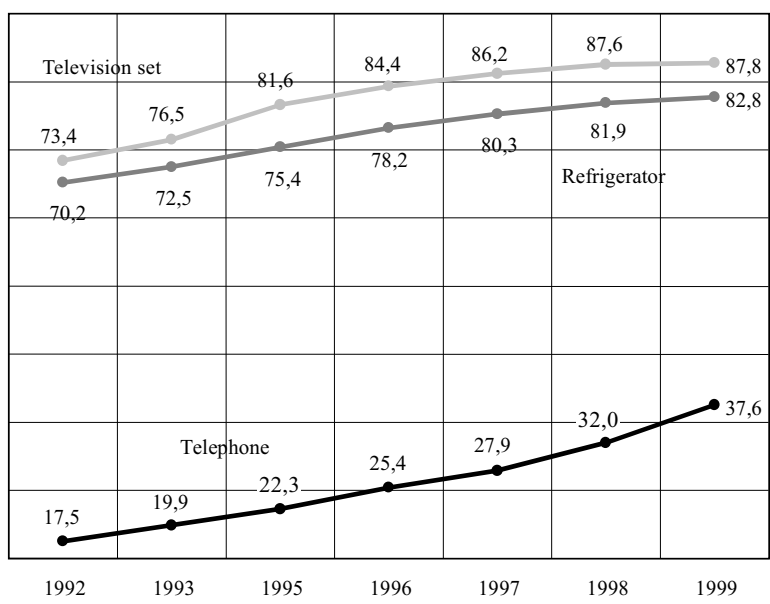

Source: IPEA, on the basis of IBGE national household surveys.

Particularly significant in this regard is the appraisal of the situation made by some specific segments of the Brazilian middle class, especially those that depend on the State and who benefited from the corporatist pattern of social policy that prevailed in the past. These people are highly dissatisfied, and there are clear signs that their quality of life has not benefited from the reforms to the same extent as other sectors. Developing social protection activities for these segments has become a growing challenge, bearing in mind the heightened competition, changes in professional requirements and lack of security characteristic of the working world and urban life in general today.

In view of this wide disparity between the objective development of social indicators and the perception that part of the population has of its situation, together with the many other social lags that persist in Brazil, it is imperative that further advances be made in the area of social policies. It is therefore of crucial importance, given the budgetary constraints and the restrictions arising from the need to guarantee fiscal and macroeconomic balance, that every effort should be made to find new and more efficient mechanisms for liaison and coordination.

(Original: Portuguese) 


\section{Bibliography}

Amadeo, E. and others (2000): Orçamento social da União, Brasilia, Secretaria de Política Econômica (SPE), Ministério de Fazenda.

Arretche, M. and V. Rodríguez (orgs.) (1999): Descentralização das políticas sociais no Brasil, São Paulo, Brazil, Fundação de Amparo à Pesquisa do Estado de São Paulo (FAPESP)/ Institute for Applied Economic and Social Research (IPEA).

Baumann, R. (1999): O Brasil nos anos 1990: uma economia em transição, Brasil: uma década em transição, Rio de Janeiro, Campus.

Brazil, Office of the President of the Republic (1996): Uma estratégia de desenvolvimento social, Brasilia.

(2001): Agenda de Governo: biênio 2001-2002, Brasilia.

Cardoso, F. H. (1994): Mãos à obra Brasil. Proposta de Governo, Brasilia.

(1998): Avança Brasil: mais 4 anos de desenvolvimento para todos. Proposta de Governo, Brasilia.

(2001): Mensagem ao Congresso Nacional: abertura da $3^{\circ}$ Sessão legislativa ordinária da $51^{\circ}$ legislatura, Brasilia, Secretaria de Comunicação, Office of the President.

Draibe, S., M. H. Guimarães de Castro and B. Azeredo (1995): The System of Social Protection in Brazil, Democracy and social policy series, Working paper, No. 3, Notre Dame, Indiana, University of Notre Dame, The Helen Kellogg Institute for International Studies.

Faria, V. E. (1986): Mudanças na composição do emprego e na estrutura de ocupações, in E. Bacha and H. Klein (eds.), $A$ transição incompleta: Brasil desde 1945, Rio de Janeiro, Paz e Terra.

(1991a): A montanha e a pedra: os limites da política social brasileira e os problemas de infância e de juventude, in A. Fausto and R. Cervini (orgs.), O trabalho e a rua: crianças e adolescentes no Brasil urbano dos anos 80, São Paulo, United Nations Children's Fund (UNICEF)/Latin American Faculty of Social Sciences (FLACSO).

(1991b): Cinquenta anos de urbanização no Brasil, Novos estudos CEBRAP, No. 29, São Paulo, Brazilian Centre for Analysis and Planning (CEBRAP), March.
(1994): The Current Social Situation in Brazil: Dilemmas and Perspectives, Democracy and social policy series, Working paper, No. 1, Notre Dame, Indiana, University of Notre Dame, The Helen Kellogg Institute for International Studies.

(1999): La política social en Brasil: una mirada comparativa, in J. Carpio and I. Novacovsky (comps.), De igual a igual: el desafio del Estado ante los nuevos problemas sociales, Buenos Aires, Fondo de Cultura Económica/Social Programme Information, Monitoring and Evaluation System (SIEMPRO)/ FLACSO.

(2000): Brasil: compatibilidade entre a estabilização e o resgate da dívida social, Pobreza e política social, Cadernos Adenauer, No. 1, São Paulo, Konrad Adenauer Foundation.

(2001): A política social no Brasil: uma perspectiva comparada, in A. Vogel and S. C. Yannoulas (coords.), Políticas públicas de trabalho e renda e controle democrático: a qualificação dos conselheiros estaduais de trabalho no Brasil, São Paulo, Julio de Mesquita Filho State University of São Paulo (UNESP).

Faria, V. E. and M. H. Guimarães de Castro (1989): Política social e consolidação democrática no Brasil, in Alexandrina Sobreira de Moura (ed.), O Estado e as políticas públicas na transição democrática, São Paulo, Editora Revista dos Tribunais, Ltd.

Faria, V. E. and E. Graeff (2000): Preparando o Brasil para o século XXI: uma experiência de governo para a mudança, in Vilmar Faria and Eduardo Graeff, (comps.), Globalização e governo progressista: novos caminhos, Reunião de Florença, 1999, Brasilia, Instituto Teotônio Vilela.

Giambiagi, F. and M. M. Moreira (1999): A economia brasileira nos anos 90, Rio de Janeiro, National Bank for Economic and Social Development.

Henriques, R. (org.) (2000): Desigualdade e pobreza no Brasil, Rio de Janeiro, Institute for Applied Economic and Social Research (IPEA). 